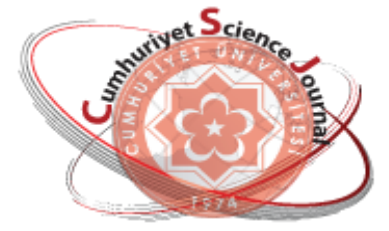

e-ISSN: $2587-246 X$

ISSN: $2587-2680$

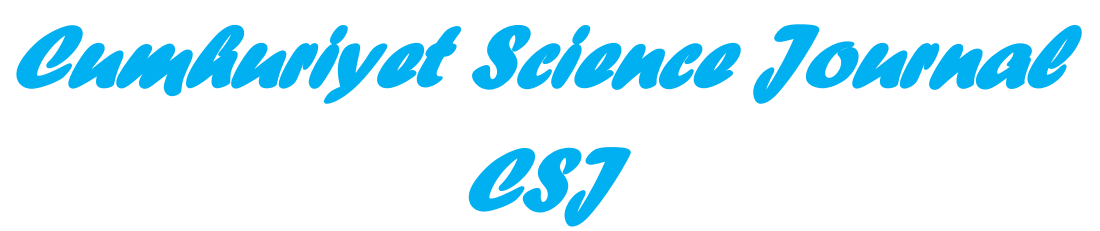

Cumhuriyet Sci. J., Vol.39-2(2018) 454-462

\title{
Realization of Concentrated Photovoltaic Module Based on Horizontally Staggered Light Guide
}

\author{
Ozgur SELIMOGLU ${ }^{1 *}$, Rasit TURAN ${ }^{2}$ \\ ${ }^{I}$ TUBITAK Space Technologies Research Institute, Middle East Technical Uni. Campus, Ankara, TURKEY \\ ${ }^{2}$ Center for Solar Energy Research and Application, Middle East Technical Uni., Ankara, TURKEY
}

Received: 17.05.2017; Accepted: 29.05.2018

http://dx.doi.org/10.17776/csj.424405

\begin{abstract}
Concentrated photovoltaic (CPV) systems have proven to be an important alternative to conventional crystalline silicon and thin film photovoltaic (PV) energy conversion systems. In CPV systems, lenses or mirrors are used to collect sunlight from a large area and to focus it onto a small area of a high efficiency photovoltaic cell. In this paper, we report the realization of a new CPV concentrator that is based on a horizontally staggered light guide system with a medium concentration level. The optical components were manufactured using a low-cost method, with PMMA as the optical material. Laser-grooved buried-contact silicon solar cells were used and these cells are specially designed and fabricated for this application to minimize the optical and electrical losses. A complete mini-module with a $15 \mathrm{~cm}$ x $15 \mathrm{~cm}$ area was assembled and tested under outdoor conditions. The test results are in good agreement with the expectations and the main problems causing losses are identified to further improve the system. It is shown that an optical efficiency of higher than $80 \%$, leading to a module power that exceeds $170 \mathrm{~W} / \mathrm{m}^{2}$, is attainable with existing Si solar cell technology with cost effective manufacturing methods.
\end{abstract}

Keywords: Concentrated Photovoltaics, Silicon solar cell, Medium level concentration, CPV, Light guide, Solar concentrator, Lens array.

\section{Yatay Adımlı Işık Yoğunlaştırıcı Temelli Yoğunlaştırmalı Fotovoltaik Modülünün Gerçekleştirilmesi}

\footnotetext{
Özet: Yoğunlaştırmalı Fotovoltaik (CPV) sistemler, konvansiyonel kristal silisyum ve ince film fotovoltaik (PV) enerji dönüşüm sistemlerine önemli bir alternatif olarak görülmektedir. Bu sistemlerde, lensler veya aynalar geniş bir alandan güneş ışığını toplayarak, küçük alanlı yüksek verimli fotovoltaik güneş hücresinin üzerine odaklamaktadır. Orta yoğunlaştırma seviyesine sahip ve yatay ışık kılavuzuna dayanan yeni bir yoğunlaştırılmış güneş paneli gerçekleştirilmiştir. Optik bileşenler, PMMA malzemesi kullanılarak düşük maliyetli bir yöntem kullanılarak üretilmiştir. Lazer oluklu gömülü temaslı silisyum güneş pilleri, optik ve elektrik kayıplarını en aza indirmek için bu uygulama için özel olarak üretilmiştir. $15 \mathrm{~cm}$ x $15 \mathrm{~cm}$ 'lik alana sahip tam bir mini modül monte edilerek test edilmiştir. Test sonuçları beklentilerle uyum içindedir ve sistemi daha da geliştirmek için kayıplara neden olan temel problemler tanımlanmıştır. Silisyum güneş pili teknolojisi ve seri üretime uygun düşük maliyetli imalat yöntemleriyle, $\% 80$ 'den daha yüksek bir optik verimliliğin ve 170 $\mathrm{W} / \mathrm{m}^{21}$ yi aşan panel gücünün elde edilebilmesinin mümkün olduğu gösterilmiştir.
}

Anahtar Kelimeler: Yoğunlaştırmalı Fotovoltaik, Silisyum güneş hücresi, Orta seviye yoğunlaştırma, CPV, Iş̧1k klavuzu, Güneş yoğunlaştırıcısı, Lens dizisi

\footnotetext{
* Corresponding author. Email address: ozgur.selimoglu@tubitak.gov.tr http://dergipark.gov.tr/csj C2016 Faculty of Science, Cumhuriyet University
} 


\section{INTRODUCTION}

Concentrated photovoltaic (CPV) systems have been shown to be an important alternative to conventional crystalline silicon and thin film photovoltaic (PV) energy conversion systems [1]. World record solar cell conversion efficiencies of up to $46.0 \%$ under concentrated light have been demonstrated using multijunction solar cells, which were developed for use in CPV systems [2]. In these systems, lenses or mirrors are used to collect sunlight from a large area and to focus it onto a small area high efficiency photovoltaic cell. This system would replace more expensive semiconductor photovoltaic cells with cheaper optics; therefore, very expensive, small area high efficiency PV cells could be used.

Although the CPV idea is very simple, systems with high concentrations have several problems, such as a very small acceptance angle, a large module thickness and excessive heating. In our previous publication [3], we discussed these problems, which are inherent to conventional point focus CPV systems, and showed that horizontally staggered light guide solar concentrators can be used to overcome most of these problems. In this approach, the incoming solar radiation is collected by several small primary concentrators and directed onto a single PV cell through a light guide that is vertically located with respect to the direction of the solar radiation. This design has the potential to attain high concentration ratios while maintaining high enough tracking tolerances. This design can also provide an easy solution to the overheating problem and smaller module thicknesses are achievable compared with conventional point focus CPV approaches.

In recent years, solar module prices have dramatically reduced. To compete with the current price level of crystalline Si-based flat PV modules, the cost of electricity generated by $\mathrm{CPV}$ systems should be further reduced. With the existing expensive high efficiency cell technology, this reduction is only possible by further reducing the cell area via an increase in the concentration level (up to 2000x), which causes complications and reduces the reliability of the systems. As a result of recent advances in single-junction GaAs based solar cells and the availability of high efficiency back-contact silicon solar cells; medium concentration approaches have become more promising and may facilitate the use of CPV systems.

Medium concentration approaches can use low cost trackers and also collect some of the diffuse radiation. With the help of tracking and large acceptance angle, most of the circumsolar diffuse radiation can be utilized for energy generation. Moreover, such systems are less problematic with respect to heating and silicon solar cells, which have a large and mature industry, can be used as the receiver [4].

Although initial theoretical studies showed promise for CPV systems that were based on horizontal concentrating light guides, the practical demonstration of this system has yet to be realized. Therefore, it is of great interest to demonstrate the feasibility of this system and to test the outcomes against the theoretical expectations. In this paper, we report the design, fabrication and test results of a medium concentration CPV unit that is based on a horizontally staggered light guide solar concentrator.

We investigated the various available production methods and materials for the concentrator to attain an optimum system design. Here, we present an optical concentrator design that is based on a lens array and light guide units that are made of PMMA. The system performs well under realistic conditions and constitutes a real alternative to conventional CPV systems. We discuss the efficiency and applicability of the system in this report. Moreover, suggestions are made for further improvements to the design and fabrication processes for future development. 


\section{HORIZONTAL CONCENTRATION AND DESIGN OF SOLAR MODULE}

\subsection{Basic concept}

The horizontal concentrating light guide solar concentrator is based on a primary lens array and a light guide with extra concentration features. Primary lens array is collecting and focusing light onto the reflective surfaces of the light guide. These reflective surfaces do not have any reflective coating and using only total internal reflection to steer the light into the light guide. Light travels in the light guide until reaching to the end of it, as shown in Figure 1.

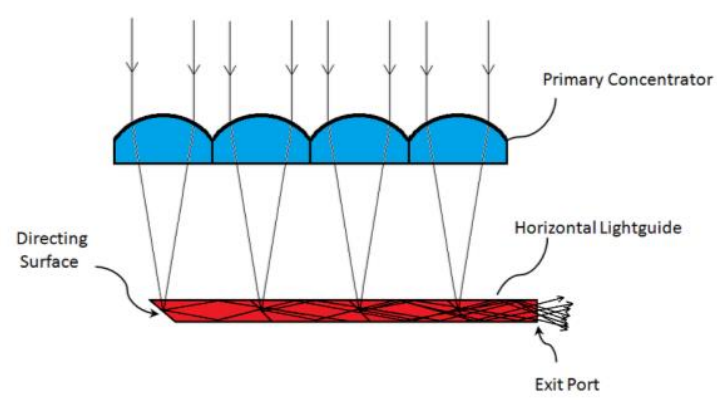

Figure 1. Concentrator Concept.

The primary concentrator is constructed as an array of aspherical lenses. These lenses do not have faceted geometries and therefore do not have associated losses, such as tip rounding losses or draft losses that are common to Fresnel lenses. Moreover, the primary lens surfaces are smooth and do not contain fine details; this geometry is therefore easy to produce and suitable for low-cost injection molding. The lenses can have a very small focal length, on the order of a few centimeters, and the focal length is the main parameter that determines the module thickness. The light guide is placed under the primary concentrator such that the light acceptance regions of the light guide coincide with the focal points of the primary concentrator lenses.

The light guide has a horizontal stepped geometry, which does not increase the light guide thickness. Moreover, the light directing surfaces do not interfere with the incoming light and do not cause any geometric loss. Therefore, this light guide is a lossless light guide that is very suitable for CPV applications where every photon is important for energy generation. The light guide is further concentrating light while light is being transported along its length via the inclusion of extra concentration features. These geometrical features, such as side cuts and end cuts are applied to the light guide to concentrate the light in the light guide. This prototype is named as the Hor-con, an abbreviation of horizontal concentrating module.

This architecture solves the thickness problem of CPV systems. Module thicknesses that are similar to flat panel PV systems can be easily achieved. Moreover, due to the strip cell geometry, the excessive heat that develops in the solar cell is spread to a line and can easily be dissipated by passive cooling elements.

\subsection{Solar cell selection}

The optical design parameters are determined with respect to the type of solar cell and to the required concentration level. Although the system presented here can easily be adapted to any type of solar cell structure with any level of concentration, we found that a medium concentration system with silicon solar cells is very promising and easy to realize. The amount of $\mathrm{Si}$ cells used in this system is approximately $4 \%$ of the cell amount used in flat silicon panels with the same panel area. This result means that a considerable reduction in the amount of solar cell area can be obtained and that the cost of the system is therefore minimized. In addition to the cost benefit, because the conversion efficiency in Si solar cells generally increases under concentrated light, we gain a significant improvement in the energy conversion. For example, if a solar cell with $22 \%$ efficiency under one sun is used as a receiver, its efficiency reaches $25 \%$ at $45 \mathrm{x}$ concentration level [5]. Moreover, silicon solar cells have already been shown to work with $27.6 \%$ efficiency under concentrated light [2].

Si solar cells with screen-printed metallization have a high series resistance loss due to a high current density at the metal finger contacts. For this reason, low series resistance laser-grooved 
buried-contact (LGBC) silicon solar cells were used in this study. In this type of solar cell, the front surface metallization is made by using electroplating into the grooves that were opened by laser ablation [6]. The cell architecture on the $\mathrm{Si}$ wafer was designed for this particular application, as shown in Figure 2. The target width of the exit port of the horizontal guide is $3.2 \mathrm{~mm}$. The active area of the solar cell should be larger than the exit port of the light guide to minimize light coupling losses. Moreover, some assembly tolerances should be introduced. Therefore, the solar cells were designed to have an active area width of $4 \mathrm{~mm}$ and a total width of $6 \mathrm{~mm}$, including busbars. LGBC solar cells with an active area of $4 \times 121 \mathrm{~mm}^{2}$ were designed and produced specifically for this project by a manufacturing company (NAREC). The layout of the solar cell structure is shown in Figure 2. Cells are obtained by laser cutting from a full silicon wafer. Strip cells have an efficiency of $14.5 \%$ under 1 sun and $17.1 \%$ under $45 \mathrm{x}$ concentrated light.

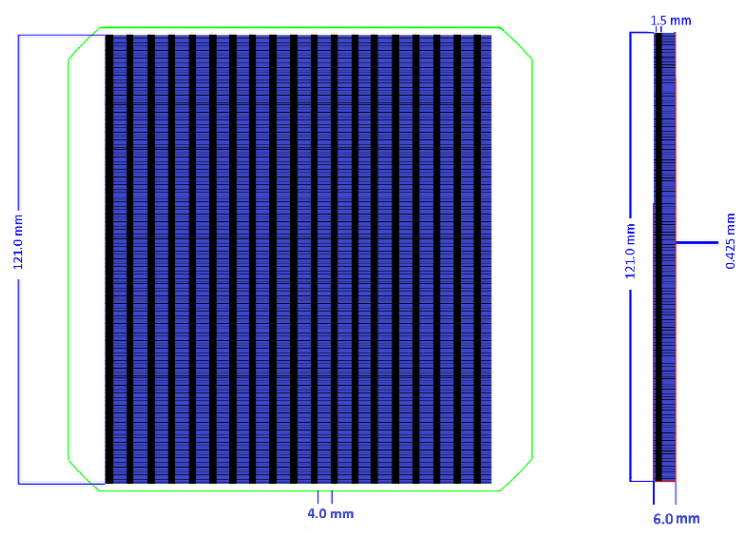

Figure 2. Buried Contact Solar Cell and Cell Strip.

\subsection{Optical design}

The Hor-con module is designed to be a medium concentration $(45 \mathrm{x})$ system that uses high quality silicon solar cells as receivers. The 3-dimensional view of the optical design is shown in Figure 3. The system consists of a lens system that is aligned with the underlying light collecting guide, as previously shown in Figure 1.

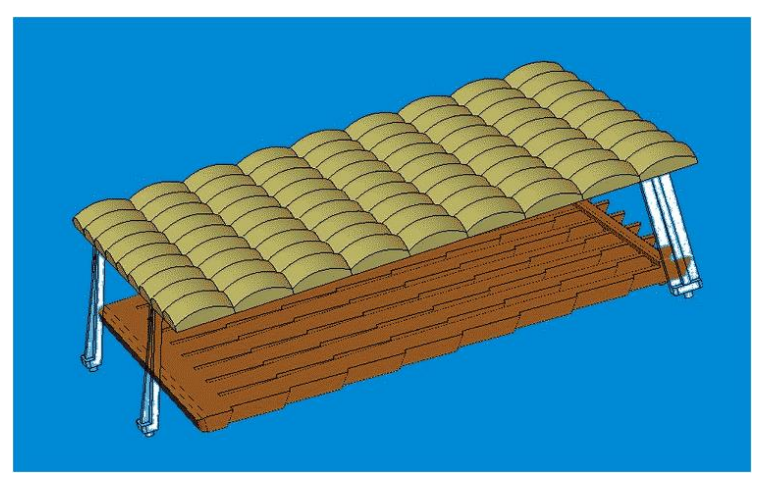

Figure 3. Concentrator Design.

The target efficiency of the optical system is $80 \%$, which is equivalent to that of most conventional Fresnel lens based systems. The loss mechanisms in this system are mainly Fresnel reflections from the optical boundaries. The boundary reflection loss is approximately $4 \%$ from every surface; because there are 3 surfaces, the total boundary reflection loss is approximately $12 \%$. The remaining $8 \%$ of the loss budget compensates for absorption losses and for scattering losses that are due to manufacturing defects.

The primary optics consists of an aspheric lens array that is produced from PMMA. The lenses have square $16 \mathrm{~mm} \times 16 \mathrm{~mm}$ apertures. The front surface of the lens has a $15.46 \mathrm{~mm}$ radius of curvature. The conic constant of the surface is -1.348 , and the $\mathrm{A}_{4}$ coefficient is 0.0000272 . The back side of the lens is flat, and the center thickness is $6 \mathrm{~mm}$. With these parameters primary lens array geometry is fully defined and an individual lens is able to focus light to a point $28 \mathrm{~mm}$ from its back surface and has an effective focal length of $32 \mathrm{~mm}$. By considering the diagonal of the square aperture of the lens, the $\mathrm{f}$-number of the lens is 1.41 .

Front surface of the lens is curved in this prototype to investigate the soiling issues. Because this lens is not a Fresnel lens, soiling may not be so severe. As a future design variant, it is also possible to design the lens array to have a flat front surface. This change will guarantee no dust accumulation at the borders of the lens while making the module a few millimeters thicker. 
The light guide is designed to collect and concentrate the light that comes from the primary lens array. Directing surfaces have no reflecting coating. The reflection is a result of total internal reflection and an angle of 55 degrees is used to satisfy total internal reflection without any loss from the directing surfaces, as shown in Figure 4. The directing surfaces are placed $16 \mathrm{~mm}$ away from each other to ensure that every directing surface is registered with a primary lens. A light-guide with a thickness of $4 \mathrm{~mm}$ is formed from the 9 branches and every branch collects light from 9 consecutive aspherical lenses.

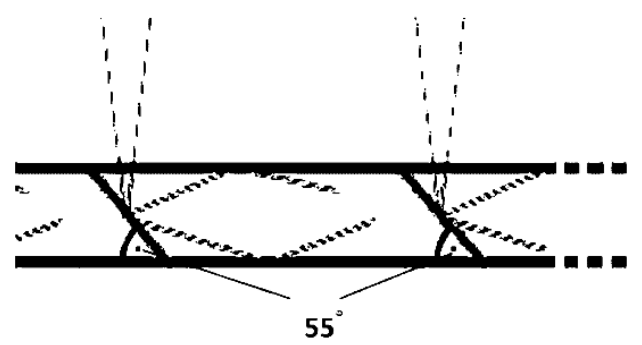

Figure 4. Directing Surfaces.

This guide thickness is the same everywhere except for at the exit port region, where it is reduced to $3.2 \mathrm{~mm}$ to increase the concentration ratio by $25 \%$ (see Figure 5 ). The exit port of the light guide is designed to have a flat top surface, enabling a cheaper and more reliable injection mold to be built.

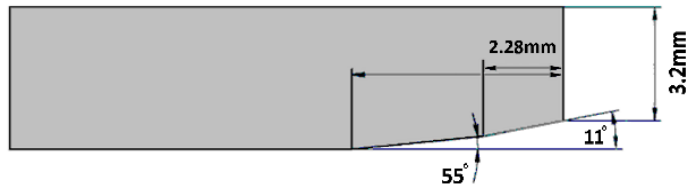

Figure 5. Exit region of light guide.

To increase the concentration level of the travelling beam, side cutting surfaces can be used [3]. Side cuts are generating new side surfaces that are tilted by $5^{\circ}$ and by $10.8^{\circ}$ with respect to the original side surface, as shown in Figure 6 . The geometry of the side cuts was calculated using ray tracing. Every injection region increases the width of the light guide by $3 \mathrm{~mm}$. Without the side cuts, the exit port would be $27 \mathrm{~mm}$ wide; the side cutting surfaces reduce this exit port width to $16 \mathrm{~mm}$ and increase the concentration by $69 \%$. The design was not optimized to reach the maximum concentration for this prototype because this is the first manufacturing run for this concentrator geometry and achievable manufacturing tolerances were unknown.

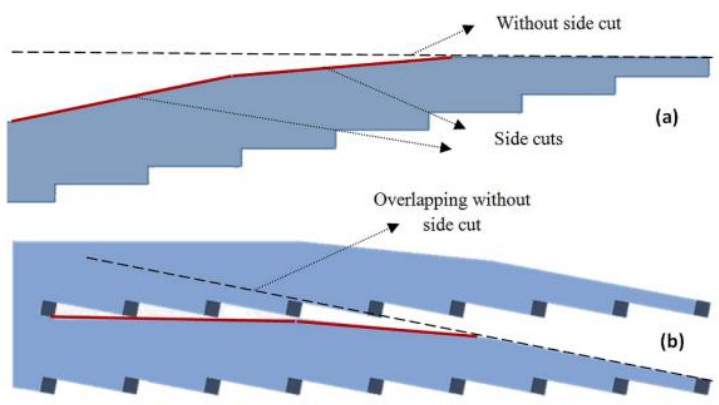

Figure 6. Side Cutting Surfaces.

\subsection{Module design}

The three dimensional schematic view of the demonstration module that has been designed in this study is shown in Figure 7. To hold the lens and the light guide in proper positions, a mechanical structure is designed. This mechanical structure is produced from aluminum and also used for heat dissipation purposes.

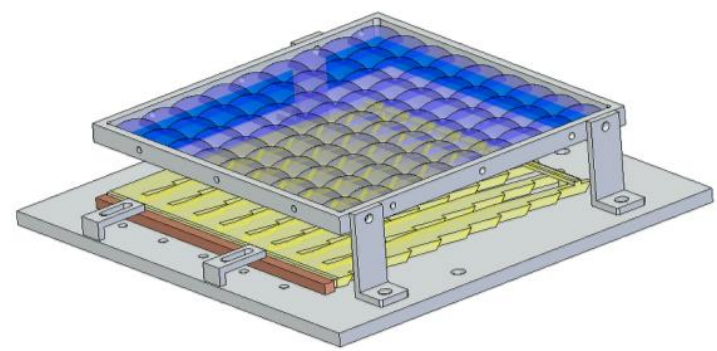

Figure 7. Hor-con Mini Module Design.

The light guide and the photovoltaic cell are attached to each other using a transparent adhesive. During operation, the cell heats up as a result of the high level $(45 \mathrm{x})$ of solar irradiation. Therefore, a copper cooling rod is bonded to the back side of the cell using an epoxy adhesive to transfer the heat to the bottom aluminum plate which has the same area with the module.

The Hor-con module that has been fabricated in this study possesses the design parameters 
shown in Table 1 . The geometric concentration ratio, acceptance angle and the module thickness are realized as a result of the optical design of the module. The primary goal of this design is the realization of the concentrator and the design has room to improvement. From this study we have obtained the manufacturing constraints and tolerances. With a further design study, it is possible to push the geometric concentration ratio or the acceptance angle to higher levels by optimizing the extra concentration features of the light guide.

Table 1. Hor-con Design Specifications.

\begin{tabular}{ll}
\hline Acceptance angle & +-2 degrees \\
\hline Geometric concentration & $45 \mathrm{x}$ \\
Optical efficiency & $80 \%$ \\
\hline Absolute concentration ratio & $30.6 \mathrm{x}$ (with respect to $1000 \mathrm{~W} / \mathrm{m}^{2}$ ) \\
\hline Module thickness & $4 \mathrm{~cm}$ \\
\hline Module efficiency & $13.6 \% \quad$ (with cell efficiency $17 \%$ under concentrated light) \\
\hline Output power & $115.6 \mathrm{~W} / \mathrm{m}^{2}$ (under $850 \mathrm{~W} / \mathrm{m}^{2}$ direct radiation) \\
\hline
\end{tabular}

Concentrator systems mainly use the direct component of solar irradiation. A direct solar irradiation of $850 \mathrm{~W} / \mathrm{m}^{2}$ is assumed for the module power estimations. The power output of the module is estimated to be $115.6 \mathrm{~W} / \mathrm{m}^{2}$ and is calculated by multiplying the incident solar power with the optical efficiency and the PV cell conversion efficiency. The target optical efficiency can be improved by using an accurate mold production and by applying appropriate antireflection coatings.

\section{MANUFACTURING}

\subsection{Optical fabrication}

A prototype of the Hor-con-45X solar concentrator is produced and tested to verify the manufacturability of the concept. PMMA material is used for both the lens array and the light guide. For the lens and guide production, a low-cost injection molding method is used. Both the light guide and the lens array are produced in the same mold for cost effectiveness. The mold used for this production is shown in Figure 8. The left side cavity is used for the primary lens and the right one is used for the light guide manufacturing.

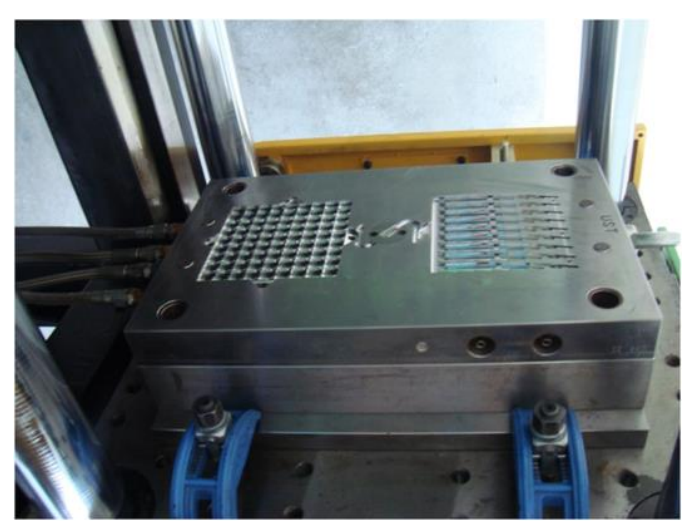

Figure 8. Injection mold used for production.

\subsection{Quality check}

The quality control of the manufactured system was performed using a standard solar simulator. The different images of the system under the solar simulator, shown in Figure 9, demonstrate the light concentration in the system. Because the collimation of the solar simulator is not good enough, a larger spot size is obtained at the focus of the primary lens array and not all the light is coupled to the waveguide. Although the simulator is not enough for absolute testing, the light coupled to the waveguide should be guided until the end of the light guide and any leakage should show the defects on the light guide. By the help of inspections under the solar simulator, we observed that the surface qualities of the side surfaces are not so good for the light guide. Most of the light loss is expected to be due to the side walls because of the surface roughness. 

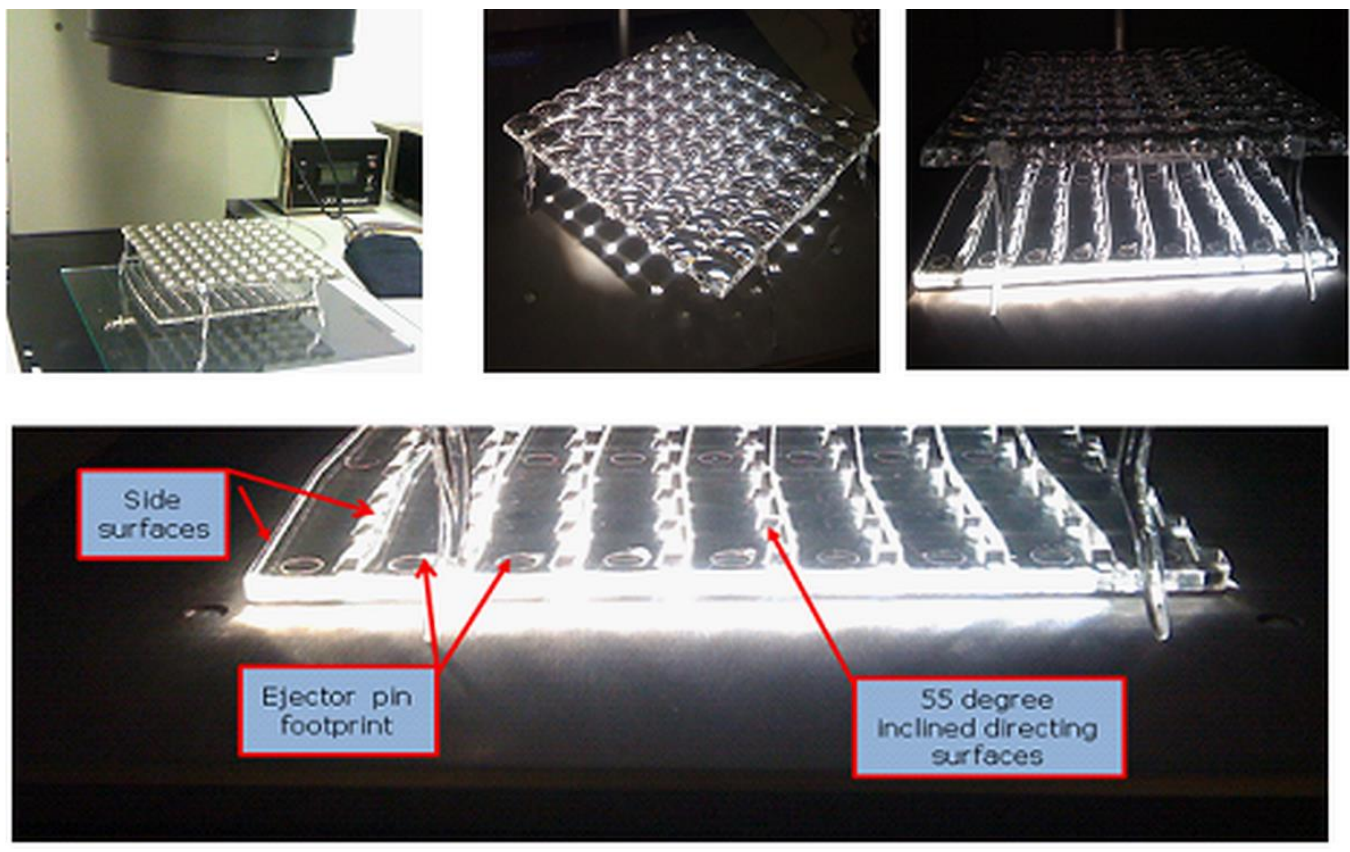

Figure 9. Concentrator tests under solar simulator.

To eject the produced optical components from the injection mold, several ejector pins were used in the design of the mold. These ejector pins push against the optical surfaces and cause surface damage. The circular light loss regions that are seen on the down side of the light guide are due to these ejector pins.

The mold that was used for production is a simple and low-cost mold. It is possible to remove these marks completely and to improve the surface roughness of the side walls by using a better serial production mold.

\subsection{Assembly:}

Most of the measurements were conducted at the outdoor test facility of the Solar Energy Research and Applications Center (GÜNAM). The solar radiation was recorded using a radiometer. The solar cell with the above dimensions was bonded to the light guide using a transparent adhesive, as shown in Figure 10.

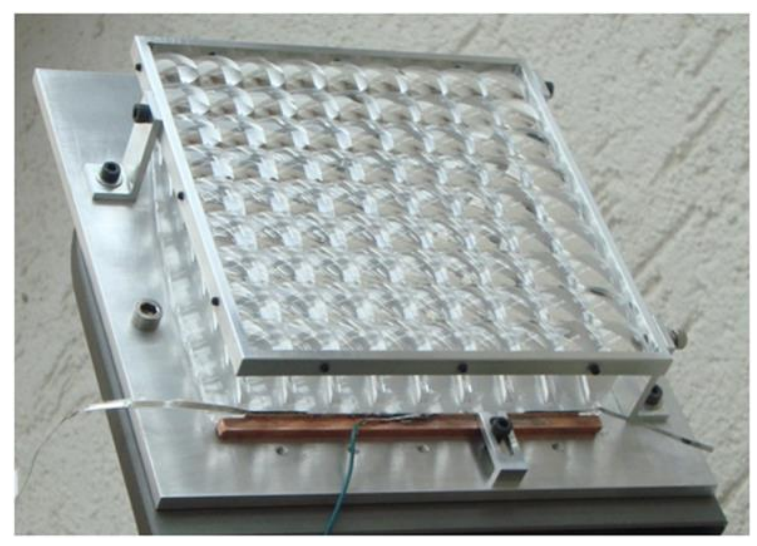

Figure 10. Hor-con Mini Module Assembly.

\section{RESULTS and DISCUSSIONS}

The current voltage (I-V) characteristic of the bare cell used for the characterization of the concentrator is shown in Figure 11. The tested cell has a $4 \mathrm{~mm} \times 121 \mathrm{~mm}$ active area and test is performed under standard test conditions $\left(1000 \mathrm{~W} / \mathrm{m}^{2}, \quad \mathrm{AM} 1.5, \quad 25^{\circ} \mathrm{C}\right)$. This cell is attached to the waveguide and used for outdoor testing. 


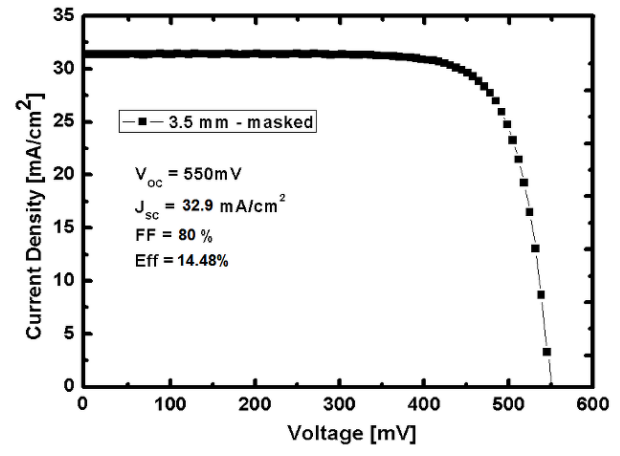

Figure 11. I-V measurement of Strip Solar Cell.

The short circuit current $\left(\mathrm{J}_{\mathrm{SC}}\right)$ and the open circuit voltage $\left(\mathrm{V}_{\mathrm{OC}}\right)$ of the cell is recorded during outdoor testing. The efficiency of the optical system is determined by comparing the outdoor test results with the laboratory measurements of the bare cell. The outdoor tests are performed under $800 \mathrm{~W} / \mathrm{m}^{2}$ direct solar irradiance which is measured with a radiometer at the test time. The outdoor tests are performed with a very short exposure to sun light, as a result cell temperature is the same as the outside temperature, which was $25^{\circ} \mathrm{C}$.

Short circuit current density is increasing linearly with the light falling on to the solar cell and therefore it is used to understand the light collection efficiency of the concentrator. Test results tabulated in Table 2 show that, the Horcon optics effectively concentrates sunlight. As shown in this table, when the cell is attached to the light guide concentrator, the short circuit current density increases from $32.9 \mathrm{~mA} / \mathrm{cm}^{2}$ to $880.0 \mathrm{~mA} / \mathrm{cm}^{2}$. Taking into account the 800 $\mathrm{W} / \mathrm{m}^{2}$ direct solar irradiation, the optical efficiency was estimated to be $74 \%$. This result is lower than the targeted $80 \%$ optical efficiency but is quite acceptable considering the several well identified defects in the light guide.

Table 2. Test Results.

\begin{tabular}{lll}
\hline $\begin{array}{l}\text { Test date/location: } \\
\text { 30 September 2012 /Ankara }\end{array}$ & \multicolumn{1}{c}{$\begin{array}{c}\text { Characterization under 1000 } \\
\text { W/m² }\end{array}$} & \multicolumn{1}{c}{$\begin{array}{c}\text { Measurement with the concentrator } \\
\text { optics }\end{array}$} \\
\hline $\begin{array}{l}\text { Short Circuit Current } \\
\text { Density }\end{array}$ & $32.9 \mathrm{~mA} / \mathrm{cm}^{2}$ & $880 \mathrm{~mA} / \mathrm{cm}^{2}$ \\
Reference Solar Irradiation & $1000 \mathrm{~W} / \mathrm{m}^{2}$ & $800 \mathrm{~W} / \mathrm{m}^{2}$ (direct) \\
Geometric Concentration & $1 \mathrm{x}$ & $940 \mathrm{~W} / \mathrm{m}^{2}$ (total) \\
Open Circuit Voltage & $550 \mathrm{mV}$ & $45 \mathrm{x}$ \\
Efficiency of the cell & $14.5 \%$ & $650 \mathrm{mV}$ \\
\hline
\end{tabular}

We observe that $\mathrm{V}_{\mathrm{OC}}$ increases under concentrated light from $550 \mathrm{mV}$ to $650 \mathrm{mV}$, as expected because of the concentration. The efficiency of the cell becomes $17.1 \%$ with this concentration level and corresponds to a relative improvement of $18 \%$ with respect to 1 sun condition. This result is in good agreement with the reported efficiency improvements in $\mathrm{Si}$ solar cells under concentration [7]. With the $74 \%$ measured optical efficiency and the attached $17.1 \%$ efficient LGBC cells, the solar panel can deliver $108 \mathrm{~W} / \mathrm{m}^{2}$ of power under 850 $\mathrm{W} / \mathrm{m}^{2}$ direct solar irradiation.

The prototype results show that the Hor-con concentrator optics can be realized using low cost injection molding. The mold used in this study has some defects and can be further improved to increase the optical performance of the system. By manufacturing a new mold, an optical efficiency of greater than $80 \%$ can easily be achieved.

To obtain a better module power output and cost effectiveness, better efficiency cells are needed. In this prototype study, LGBC cells with $17.1 \%$ efficiency under concentration are used. This front contact cells have high shading effect as a result of dense fingers to reach low series resistance. The efficiency can be improved by using interdigitated back-contact (IBC) solar cells. Back-contact cells can easily reach an efficiency of greater than $25 \%$ under concentrated light [8]. Therefore, with $80 \%$ optical efficiency and $25 \%$ cell efficiency, a module efficiency of greater than $20 \%$ is 
reasonable. This efficiency corresponds to a module power output of $170 \mathrm{~W} / \mathrm{m}^{2}$ under $850 \mathrm{~W} / \mathrm{m}^{2}$ direct solar radiation.

\section{CONCLUSIONS}

In this study, we have demonstrated the realization of a new CPV approach that is based on horizontally staggered light guide unit, named as Hor-con module. The test results confirm an optical efficiency of $74 \%$, while the target efficiency was $80 \%$.

This prototype study shows that the Hor-con module is easy to manufacture and can be realized with cost effective materials. The mold used in this study has some identified defects and can be improved to increase the optical performance of the system. By manufacturing a new mold, an optical efficiency of greater than $80 \%$ can easily be achieved. Therefore, with an optical efficiency greater than $80 \%$ and a cell efficiency of $25 \%$, module efficiency greater than $20 \%$ is achievable. Such a module can generate more than $170 \mathrm{~W} / \mathrm{m}^{2}$ under standard test conditions.

The Hor-con module is a medium concentration CPV system. Medium concentration systems can use cost effective and mature high efficiency silicon solar cells. Because of loose manufacturing tolerances and more flexible tracking requirements, medium concentration systems can be a reliable and cost effective alternative to present $\mathrm{PV}$ technologies.

\section{REFERENCES}

[1] G. Zubi, J.L., Bernal Agustin and V.G., Fracastoro, "High concentration photovoltaic systems applying III-V cells," Renewable and Sustainable Energy Reviews, 13 (2009) 2645-2652.

[2] NREL, "NREL," National Center for Photovoltaics, 2018. [Online]. Available: https://www.nrel.gov/pv/assets/images/ efficiency-chart.png. [Accessed $09 \quad 05$ 2018].

[3] O. Selimoglu and R. Turan, "Exploration of the horizontally staggered light guides for high concentration CPV applications," Optics Express, 20-17 (2012) 1913719147.

[4] Kurtz S., "Opportunities and Challenges for Development of a Mature Concentrating Photovoltaic Power Industry," NREL, 2012.

[5] Green M.A., Jianhua Z., Blakers A.W., Taouk M., and Narayanan S., "25-Percent efficient low-resistivity silicon concentrator solar cells," Electron Device Letters, IEEE, pp. (1986) 583-585.

[6] Morilla C., Vivar M., Russel R., Fernandez J., and Sala G., "Developments in the Optimisation of Laser Grooved Burried Contact Cells for use in Concentration Systems," in 22nd European Photovoltaic Solar Energy Conference and Exhibition, Milan, 2007.

[7] Mohr A., "Silicon Concentrator Cells In A Two-Stage Photovoltaicsystem With A Concentration Factor Of 300X," Albert Ludwig University of Freiburg, Freiburg im Breisgau, 2005.

[8] Sinton R., Kwark Y., Gan J., and Swanson R.M., "27.5-Percent Silicon Concentrator Solar Cells," IEEE Electron Device Letters , 7-10 (1986) 567-569. 